\title{
In Vitro Screening Assay for Detecting Aromatase Activity Using Rat Ovarian Microsomes and Estrone ELISA
}

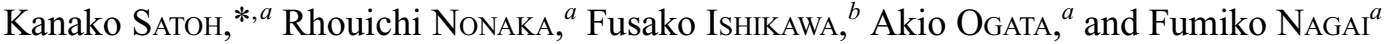 \\ ${ }^{a}$ Department of Environmental Health and Toxicology, Tokyo Metropolitan Institute of Public Health; and ${ }^{b}$ Department of \\ Food Safety, Tokyo Metropolitan Institute of Public Health; 3-24-1 Hyakunincho, Shinjuku-ku, Tokyo 169-0073, Japan. \\ Received December 3, 2007; accepted January 8, 2008; published online January 10, 2008
}

\begin{abstract}
Aromatase, a key steroidogenic enzyme that catalyses the conversion of androgens to estrogens, present a target for endocrine disrupting chemicals. However, little is known about the effect of pollutants on aromatase enzymes. In this study, we first optimized a non-radioisotope aromatase assay using rat ovarian microsomes in vitro and measuring the estrone level with an enzyme-linked immunosorbent assay (EIA method). The sensitivity of the EIA method was about ten times as high as that of the radioisotope (RI) method. A significant positive correlation was indicated between EIA and RI method. We used this EIA assay system to investigate the effects of aromatase activity on 45 chemicals that had previously been reported to act as endocrine disruptors or to have the possibility of having such an effect. Six of the chemicals, rose bengal, erythrosine, phloxine, allura red, gallic acid, and tributyltin, inhibited aromatase activity. The inhibitory effect of rose bengal was the strongest

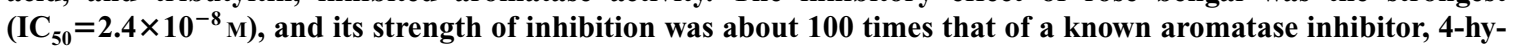
droxy-androstenedione $\left(\mathrm{IC}_{50}=2.6 \times 10^{-6} \mathrm{M}\right)$ but was about $1 / 25$ that of fadrazole $\left(\mathrm{IC}_{50}=1.0 \times 10^{-9} \mathrm{M}\right)$. It is thought that this EIA method would be useful for measuring the aromatase activity of microstructures.
\end{abstract}

Key words aromatase; endocrine disrupter; rose bengal; enzyme-linked immunosorbent assay; food additive; red dye

The screening of chemicals for endocrine disrupting (ED) activity is a major goal of research groups and regulatory agencies worldwide. The Endocrine Disrupter Screening and Testing Advisory Committee (EDSTAC) were chartered by the US Environmental Protection Agency for this purpose and have now proposed a series of in vitro assays. We previously established tier-1 screening non-radioisotope (non-RI) assays, for example, an estrogen receptor (ER) binding assay and an androgen receptor (AR) binding assay, and reporter gene assays to detect estrogenic, anti-estrogenic, androgenic, and anti-androgenic chemicals. We reported on the endocrine disrupting effects of many chemicals (e.g., parabens, bisphenol A-related compounds, alkyl phenols, styrene oligomers) using these methods. ${ }^{1-6)}$ However, these chemicals may also disrupt biological function by other mechanism, such as altering hormone biosynthetic pathways. Therefore, EDSTAC recommended the establishment of in vitro aromatase assay as the titer-1 screening.

Aromatase (an isoform of P450; CYP 19) is a key enzyme in the conversion of androgens to estrogens and has an important role in maintaining a homeostatic balance between androgen and estrogen. ${ }^{7)}$ In vitro assay methods have been developed to measure aromatase activity that are determined by measurement of the amount of ${ }^{3} \mathrm{H}$-water released upon enzymatic conversion of RI-labeled androstendione (RI method). ${ }^{8-10)}$ Recently, Ohno et al. ${ }^{11)}$ developed a novel nonRI cell-based assay that can detect both inhibition and induction of aromatase. This method was performed using KGN cells, which are a steroidogenic human ovarian granulosalike tumor cell line that was established from a patient with invasive granulosa cell carcinoma. ${ }^{12}$ ) They cultured KGN cells and androstendione with chemicals and measuring the estrone level in the culture medium with a specific enzymelinked immunosorbent assay (ELISA). ${ }^{11)}$ Aromatase is expressed in the ovary, testis, brain, adipose tissue and placenta in humans. Since the human placenta is a particularly rich source of the enzyme, we also used it to assay aromatase in- hibitors. ${ }^{10)}$ However, it is difficult to obtain the human placenta in Japan, because a complex procedure is accompanied. When the experimenter uses RI, it is necessary to observe the Japanese law, and to construct facilities in conformity to the law. In the rat, the primary site of aromatase activity is the ovary, and the rat ovary assay is useful for predicting possible ED in rats, and as an aid to mechanistic studies of ED effects observed in the rat. ${ }^{13)}$ This report describes the determination of aromatase enzyme activity using rat ovarian microsomes and measuring the estrone level with an ELISA assay (EIA method). Rats were used because endocrine disruption studies are most commonly carried out in this species. Using the EIA method and the RI method, we tested the aromatase activity of 45 chemicals (Table 1) that have previously been reported to act as ED chemicals (having estrogenic and/or androgenic effects, or aromatase inhibitors). The results of the EIA method and the RI method showed a high correlation. Any researcher who doesn't have RI facility can measure the aromatase activity using this EIA method. Our results demonstrated that the EIA method was more sensitive than the RI method.

\section{MATERIALS AND METHODS}

Reagents The estrone ELISA kit was provided by Yanaihara Institute Inc. (Fujinomiya, Shizuoka, Japan). Fadrozole was provided by Novartis Pharma Inc. Japan. 4-Hydroxy-androstene-3,17-dion, phenylmethylsulfonyl fluoride (PMSF), and $\beta$-nicotinamide-adenine dinucleotide phosphate (NADPH) were purchased from Sigma (St. Louis, MO, U.S.A.). $[1 \beta$ $\left.{ }^{3} \mathrm{H}\right]$-Androstenedione $\left(25.3 \mathrm{Ci} / \mathrm{mmol} ;{ }^{3} \mathrm{H}\right.$-distribution: $1 \beta=$ $74-79 \%$ ) was purchased from Du Pont-New England $\mathrm{Nu}-$ clear (U.S.A). Other reagents were of the highest grade commercially available.

Chemicals The test chemicals were used of the highest grade commercially available or the grade used for environmental analysis. The source and CAS No. are listed in Table 
1. These chemicals were dissolved in dimethyl sulfoxide (DMSO) for the aromatase assay. The final concentration of DMSO was $0.1 \%$ in the reaction mixture.

Preparation of Rat Ovary Microsome Rats (Crlj: $\mathrm{CD}(\mathrm{SD})$ ) were individually housed in cages, and maintained under conditions controlled at $22-24^{\circ} \mathrm{C}, 45-65 \%$ humidity, 12-h lighting, and 10 ventilations per hour. All animal were performed to procedures approved under institute guidelines for the care and use of laboratory animals. After rats (10-15 weeks) anesthetized with dimethyl ether via the respiratory tract, the ovaries were excised and weighed as the wet weights. Rat ovary microsomes were obtained by a modification of the methods described in the previous reports. ${ }^{8,9)}$ Rat ovaries were homogenized in steroidogenic buffer $(20$ mM $N$-tris[hydroxymethyl]methyl-2-aminomethane sulfonic acid (TES), $10 \mathrm{~mm}$ EDTA, $150 \mathrm{~mm} \mathrm{KCl}, 0.1 \mathrm{~mm}$ PMSF, $\mathrm{pH}$ 7.3). The homogenate was centrifuged at $2000 \boldsymbol{g}$ for $5 \mathrm{~min}$. The supernatant was centrifuged at $40000 \boldsymbol{g}$ for $60 \mathrm{~min}$. The precipitate was resuspended in steroidogenic buffer and protein was determined according to Bradford, ${ }^{14)}$ and the samples were then stored at $-80^{\circ} \mathrm{C}$ until needed for experiments.

Table 1. Data on Chemicals and Their Effects on Aromatase Activity

\begin{tabular}{|c|c|c|c|c|c|c|c|}
\hline \multirow{2}{*}{$\begin{array}{l}\text { Chemicals } \\
\text { family }\end{array}$} & \multirow{2}{*}{ Chemicals } & \multirow{2}{*}{ CAS No. } & \multirow{2}{*}{ Supplier } & \multicolumn{2}{|c|}{$\begin{array}{l}\text { Inhibition of } \mathrm{A} \mathrm{A}^{a)} \\
\text { in this assay }\left(\mathrm{IC}_{50} \mathrm{M}\right)\end{array}$} & \multirow{2}{*}{$\begin{array}{l}\text { Reported } \mathrm{IC}_{50}(\mathrm{M}) \\
\text { by human placenta } \\
\text { microsomal } \\
\text { assay }\end{array}$} & \multirow{2}{*}{$\begin{array}{l}\text { Reported } \mathrm{IC}_{50} \\
\text { (M) by KGN } \\
\text { cells assay }{ }^{11)}\end{array}$} \\
\hline & & & & EIA & RI & & \\
\hline $\begin{array}{l}\text { Aromatase } \\
\text { inhibitor }\end{array}$ & $\begin{array}{l}\text { Fadrozole } \\
\text { 4-Hydroxy-androstenedione }\end{array}$ & $\begin{array}{r}102676-31-3 \\
566-48-3\end{array}$ & $\begin{array}{l}\text { Novelties Pham } \\
\text { Sigma }\end{array}$ & $2.6 \times 10^{-6}$ & $\begin{array}{l}1.0 \times 10^{-9} \\
1.0 \times 10^{-6}\end{array}$ & $\begin{array}{l}\left.5.4 \times 10^{-9} 15\right) \\
\left.6.0 \times 10^{-7} 16\right)\end{array}$ & $1.2 \times 10^{-9}$ \\
\hline Dyes & $\begin{array}{l}\text { Rose bengal } \\
\text { Erythrosine } \\
\text { Phloxine } \\
\text { Allura red } \\
\text { Acid red }\end{array}$ & $\begin{array}{r}632-69-9 \\
16423-68-0 \\
18472-87-2 \\
25956-17-6 \\
3520-42-1\end{array}$ & $\begin{array}{l}\text { Tokyo Kasei } \\
\text { Tokyo Kasei } \\
\text { Tokyo Kasei } \\
\text { Tokyo Kasei } \\
\text { Tokyo Kasei }\end{array}$ & $\begin{array}{l}2.4 \times 10^{-8} \\
1.5 \times 10^{-7} \\
3.2 \times 10^{-7} \\
2.4 \times 10^{-5} \\
\mathrm{NE}^{c)}\end{array}$ & $\begin{array}{l}2.5 \times 10^{-8} \\
4.2 \times 10^{-7} \\
8.8 \times 10^{-7} \\
42 \%^{b)} \\
\mathrm{NE}\end{array}$ & & \\
\hline Tins & $\begin{array}{l}\text { Tri- } n \text {-butyltin chloride } \\
\text { Tri- } n \text {-phenyltin chloride } \\
\text { Di- } n \text {-butyltin dichloride }\end{array}$ & $\begin{array}{r}1461-22-9 \\
639-58-7 \\
638-18-1\end{array}$ & $\begin{array}{l}\text { Tokyo Kasei } \\
\text { Wako } \\
\text { Aldrich }\end{array}$ & $\begin{array}{l}1.0 \times 10^{-4} \\
\mathrm{NE} \\
\mathrm{NE}\end{array}$ & $\begin{array}{l}1.0 \times 10^{-4} \\
\mathrm{NE} \\
\mathrm{NE}\end{array}$ & $\left.6.2 \times 10^{-5} 17\right)$ & $\begin{array}{l}+/-f) \\
+/-f)\end{array}$ \\
\hline Plants & $\begin{array}{l}\text { Gallic acid } \\
\text { Pentagalloyl glucose } \\
\text { Galloyl-paeoniflorin } \\
\text { Daidzin } \\
\text { Genistin } \\
\text { Genistein } \\
\text { Daidzein } \\
\text { Apigenin } \\
\text { Flavone } \\
\text { 7-Hydroxyflavone }\end{array}$ & $\begin{array}{r}149-91-7 \\
122653-70-7 \\
414-82-7 \\
552-66-9 \\
529-59-9 \\
446-72-0 \\
486-66-8 \\
520-36-5 \\
525-82-6 \\
6665-86-7\end{array}$ & $\begin{array}{l}\text { Wako } \\
\text { P. R. }{ }^{d)} \\
\text { P. R. }{ }^{d)} \\
\text { Wako } \\
\text { Wako } \\
\text { Wako } \\
\text { Wako } \\
\text { Sigma } \\
\text { Wako } \\
\text { Wako }\end{array}$ & $\begin{array}{l}3.4 \times 10^{-5} \\
\mathrm{NE} \\
\mathrm{NE} \\
\mathrm{NE} \\
\mathrm{NE} \\
\mathrm{NE} \\
\mathrm{NE} \\
5.7 \times 10^{-6} \\
3.5 \times 10^{-5} \\
9.1 \times 10^{-7}\end{array}$ & $\begin{array}{c}1.0 \times 10^{-4} \\
\mathrm{NE} \\
\mathrm{NE} \\
\mathrm{NE} \\
\mathrm{NE} \\
\mathrm{NE} \\
\mathrm{NE} \\
- \\
- \\
-\end{array}$ & $\begin{array}{l}\left.2.9 \times 10^{-6} 18\right) \\
1.0 \times 10^{-519)} \\
\left.5.0 \times 10^{-7} 19\right)\end{array}$ & $\begin{array}{c}2.6 \times 10^{-5} \\
\left.\text { about } 40 \%^{g}\right) \\
5.3 \times 10^{-6}\end{array}$ \\
\hline Herbicides & $\begin{array}{l}o, p^{\prime}-\mathrm{DDT} \\
p, p^{\prime}-\mathrm{DDT} \\
p, p^{\prime}-\mathrm{DDE} \\
p, p^{\prime}-\mathrm{DDD}\end{array}$ & $\begin{array}{l}53-19-0 \\
53-29-3 \\
72-55-9 \\
72-54-8\end{array}$ & $\begin{array}{l}\text { Wako } \\
\text { Wako } \\
\text { Wako } \\
\text { Wako }\end{array}$ & $\begin{array}{l}\mathrm{NE} \\
\mathrm{NE} \\
\mathrm{NE} \\
\mathrm{NE}\end{array}$ & $\begin{array}{l}\mathrm{NE} \\
\mathrm{NE} \\
\mathrm{NE} \\
\mathrm{NE}\end{array}$ & & $+/-f)$ \\
\hline Parabens & $\begin{array}{l}\text { Isobutyl } p \text {-hydroxybenzoate } \\
\text { Butyl } p \text {-hydroxybenzoate } \\
\text { Isopropyl } p \text {-hydroxybenzoate } \\
\text { Propyl } p \text {-hydroxybenzoate } \\
\text { Ethyl } p \text {-hydroxybenzoate } \\
\text { Methyl } p \text {-hydroxybenzoate }\end{array}$ & $\begin{array}{r}4247-02-3 \\
94-26-8 \\
4191-73-5 \\
96-48-0 \\
35285-68-8 \\
99-76-3\end{array}$ & $\begin{array}{l}\text { Tokyo Kasei } \\
\text { Tokyo Kasei } \\
\text { Tokyo Kasei } \\
\text { Tokyo Kasei } \\
\text { Tokyo Kasei } \\
\text { Tokyo Kasei }\end{array}$ & $\begin{array}{l}\mathrm{NE} \\
\mathrm{NE} \\
\mathrm{NE} \\
\mathrm{NE} \\
\mathrm{NE} \\
\mathrm{NE}\end{array}$ & $\begin{array}{l}\mathrm{NE} \\
\mathrm{NE} \\
\mathrm{NE} \\
\mathrm{NE} \\
\mathrm{NE} \\
\mathrm{NE}\end{array}$ & & \\
\hline $\begin{array}{l}\text { Styrene } \\
\text { oligomers }\end{array}$ & $\begin{array}{l}\text { 1,3-Diphenylpropane } \\
\text { 2,4-Diphenyl-1-butene } \\
\text { cis-1,2-Diphenylcyclobutane } \\
\text { trans-1,2-Diphenylcyclobutane } \\
\text { 2,4,6-Triphenyl-1-hexene } \\
\text { 1a-Phenyl-4a-(1'-phenylethyl)tetralin } \\
\text { 1a-Phenyl-4e-(1'-phenylethyl)tetralin } \\
\text { 1e-Phenyl-4a-(1'-phenylethyl)tetralin } \\
\text { 1e-Phenyl-4e-(1'-phenylethyl)tetralin }\end{array}$ & $\begin{array}{r}5299-64-9 \\
16606-47-6 \\
7694-30-6 \\
20071-09-4 \\
18964-53-9 \\
- \\
- \\
-\end{array}$ & $\begin{array}{l}\text { Wako } \\
\text { Wako } \\
\text { Wako } \\
\text { Wako } \\
\text { Wako } \\
\text { Wako } \\
\text { Wako } \\
\text { Wako } \\
\text { Wako }\end{array}$ & $\begin{array}{l}\mathrm{ND}^{e)} \\
\mathrm{ND} \\
\mathrm{ND} \\
\mathrm{ND} \\
\mathrm{ND} \\
\mathrm{ND} \\
\mathrm{ND} \\
\mathrm{ND} \\
\mathrm{ND}\end{array}$ & $\begin{array}{l}\mathrm{NE} \\
\mathrm{NE} \\
\mathrm{NE} \\
\mathrm{NE} \\
\mathrm{NE} \\
\mathrm{NE} \\
\mathrm{NE} \\
\mathrm{NE} \\
\mathrm{NE}\end{array}$ & & \\
\hline Antioxidants & $\begin{array}{l}\text { Butylhydroxytoluene } \\
\text { Butylhydroxyanisole } \\
\text { 4,4'-Butylidenebi(6-t-butyl- } m \text {-cresol) } \\
\text { 2,4-di-t-Butylphenol } \\
\text { 2,2,4-Trimethyl-1,3-pentanediol } \\
\text { diisobutyrate } \\
\text { 4,4'-Thiobi(6- } t \text {-butyl- } m \text {-cresol) }\end{array}$ & $\begin{array}{r}95-82-9 \\
025013-16-5 \\
85-60-9 \\
96-76-4 \\
6486-50-0 \\
96-69-5\end{array}$ & $\begin{array}{l}\text { Wako } \\
\text { Wako } \\
\text { Tokyo Kasei } \\
\text { Wako } \\
\text { Tokyo Kasei }\end{array}$ & $\begin{array}{l}\text { ND } \\
\text { ND } \\
\text { ND } \\
\text { ND } \\
\text { ND }\end{array}$ & $\begin{array}{l}\mathrm{NE} \\
\mathrm{NE} \\
\mathrm{NE} \\
\mathrm{NE} \\
\mathrm{NE}\end{array}$ & & \\
\hline
\end{tabular}

a) A A; aromatase activity. b) \% inhibition at $10^{-4} \mathrm{M} . \quad$ c) No inhibition at $10^{-4} \mathrm{M} . \quad$ d) Purification by Paeoniae Radex. e) Not determined. $f$ ) $+/-$; the reduction of aromatase activity and cell toxicity were parallel. $\left.{ }^{9}\right)$ g) \% inhibition at $10^{-5} \mathrm{M}$. Purity: $95-99 \%$ or that of the grade used for environmental analysis. Tokyo Kasei: Tokyo Kasei Kogyo Co., Ltd., Japan, Wako: Wako Pure Chemical Industries, Ltd., Japan. 
Aromatase Assay Aromatase activity was determined according to the method previously described. ${ }^{9}{ }^{9}$ Briefly, the incubation mixture contained $10 \mathrm{~mm}$ NADPH, $10 \mu \mathrm{l}$ of rat ovary microsomes (EIA method: $0.45 \mu \mathrm{g}$ protein/tube, RI method: $5.0 \mu \mathrm{g}$ protein/tube), $12 \mu \mathrm{l}$ of various concentrations of test chemicals, $200 \mathrm{~nm}$ 4-hydroxy-androstene-3,17-dione (RI method: $\left[1 \beta-{ }^{3} \mathrm{H}\right]$-androstenedione $5 \times 10^{5} \mathrm{dpm}$ ), and 50 mM phosphate buffer $(\mathrm{pH} 7.5)$ at a final incubation volume of $120 \mu \mathrm{l}$. Incubations were performed at $37^{\circ} \mathrm{C}$ for $30 \mathrm{~min}$.

Measurement of Aromatase Activity EIA Method: Incubations were terminated by heating at $100^{\circ} \mathrm{C}$ for $10 \mathrm{~min}$. One hundred micro liters of the reaction mixture was used as the sample for analysis using the estrone ELISA kit as described in the manufacturer's instructions. Briefly, goad antirabbit IgG coated 96 well microplate was wash using a wash solution, and then solution of biotin-labeled estrone, estrone standard or chemicals, and estrone specific antibody were reacted at $4{ }^{\circ} \mathrm{C}$ overnight $(17-19 \mathrm{~h})$ with or without $50 \mathrm{pg} / \mathrm{ml}$ estrone. After aspirate the solution and wash all wells 3 times with a wash solution, and the substrate solution was added into all wells at $25^{\circ} \mathrm{C}$ for $2 \mathrm{~h}$. After the fourth wash, a solution of the $o$-phnylenediamine was added at $25^{\circ} \mathrm{C}$ for $20 \mathrm{~min}$, and then the stop solution was added into all wells. The developed color was read at $450 \mathrm{~nm}$ on a micro-titer spectrophotometer (SunriseRemote, TECAN, Copenhagen, Denmark), and the estrone concentration was calculated based on a standard curve (eight estrone concentrations; 0, 1.2, 4.8, $19.5,78.1,312.5,1250,5000 \mathrm{pg} / \mathrm{ml}$ ) and using the software attached to SunriseRemote.

RI Method: Incubations were terminated by the addition of $60 \mu \mathrm{l}$ of $30 \%$ TCA followed by $60 \mu \mathrm{l}$ of $0.01 \%$ dextran-charcoal. The reaction mixtures were shaken for $10 \mathrm{~min}$, and after centrifugation at $700 \mathrm{~g}$ for $5 \mathrm{~min}, 200 \mu \mathrm{l}$ of the supernatants were added to $800 \mu \mathrm{l}$ of water and $2 \mathrm{ml}$ of $\mathrm{CHCl}_{3}$, followed by shaking for $5 \mathrm{~min}$. After centrifugation at $700 \mathrm{~g}$ for $5 \mathrm{~min}$, $0.5-\mathrm{ml}$ aliquots of supernatant were mixed with scintillation liquid for counting of ${ }^{3} \mathrm{H}_{2} \mathrm{O}$ production.

Statistical Analysis All statistical analysis and $\mathrm{IC}_{50}$ values were determined using KaleidaGraph ver. 4 software (Synergy Software, PA, U.S.A.). The data represented the mean values of three independent experiments $(n=3-6)$.

\section{RESULTS}

Optimization of the Assay Conditions To optimize the sensitivity of the assay system using rat ovary microsomes

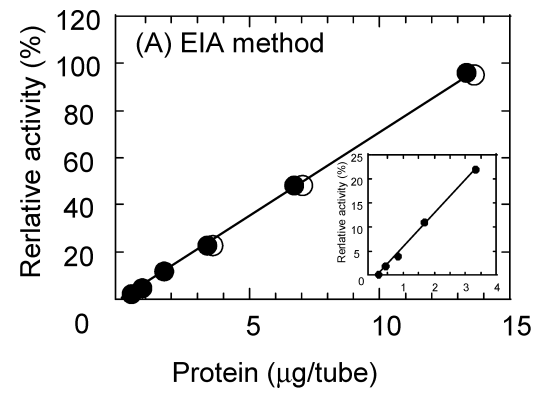

( $0.45 \mu \mathrm{g}$ protein/tube), first we examined the incubation time ( $0-45 \mathrm{~min})$. The estrone level (aromatase activity) rose linearly until $30 \mathrm{~min}$ (Fig. 1). This incubation time was corresponding to Odum's ${ }^{13)}$ report (rat ovary microsome). Using 3.3 and $6.6 \mu \mathrm{g}$ protein/tube of rat ovary microsome, the same results were obtained (data not shown). The concentrations of $\beta$-NADPH and 4-hydroxy-androstene-3,17-dione in the assay mixture and incubation temperature followed the previous report. ${ }^{9}$ ) The calibration curves were made within the range of $0.28-13.3 \mu \mathrm{g}$ protein/tube. The aromatase activity could be measured linearly from $0.42-13.3 \mu \mathrm{g}$ protein/tube using the EIA method (Fig. 2A), and the regression equation of the calibration curve when $X$ was the protein concentration and $Y$ was the relative activity value (with the aromatase activity at $13.3 \mu \mathrm{g}$ protein/tube taken as 100) was $y=6.88 x$ -0.88 . When the aromatase activity was measured using the RI method (Fig. 2B), $3.3 \mu \mathrm{g}$ protein/tube was the minimum detectable level of the protein, and the activity increased linearly up to $13.3 \mu \mathrm{g} /$ tube, with a regression equation of $y=7.97 x-12.32$ for the calibration curve. Concentration of $0.1 \%$ DMSO has not effect on these activities (Figs. 2A, B). The aromatase activity was measured at the same time by the EIA and RI methods, and the values obtained were compared. The values obtained using the EIA and RI methods were positively correlated, with a Pearson's correlation coefficient of $0.90(p<0.01)$ (Fig. 3).

The effects of two typical aromatase inhibitors were examined by the EIA and RI methods. Both fadrozole (Fig. 4A) and 4-hydroxy-androstenedione (Fig. 4B) inhibited the aromatase activity, and the inhibitory effects were concentration-dependent. From the inhibition curves, the concentrations of the inhibitors giving half-maximal inhibition $\left(\mathrm{IC}_{50}\right)$ were obtained. The $\mathrm{IC}_{50}$ values obtained by the EIA and $\mathrm{RI}$

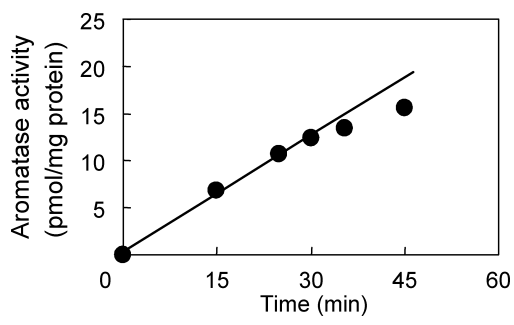

Fig. 1. Effect of Incubation Time on Estrone Production

Rat ovary microsomes $(0.45 \mu \mathrm{g} /$ tube $)$ were incubated as described in Materials and Methods. Incubation time was varied. The average values from 5 separate experiments are shown. The S.D. was less than $2.6 \%$

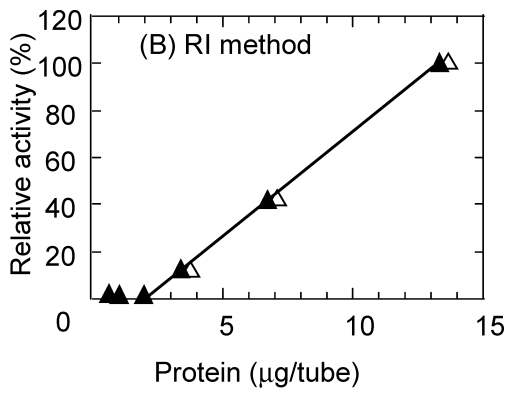

Fig. 2. Effects of the Amount of Rat Ovary Microsomal Proteins on Estrone (EIA Method) and ${ }^{3}$ H-Water (RI Method) Production

The incubation time was $30 \mathrm{~min}$. Aromatase activities in the presence of $13.3 \mu \mathrm{g}$ of rat ovary microsomes/tube were taken as $100 \%$. (A) EIA method. Lower concentration protein is shown in the inset. - ; no contain DMSO. O; 0.1\% DMSO. (B) RI method. $\mathbf{\Delta}$; no contain DMSO. $\triangle$; $0.1 \%$ DMSO. The average values from 3 separate experiments are shown. The S.D. was less than $2.3 \%$. 
methods were almost equivalent, and the $\mathrm{IC}_{50}$ values of fadrozole and 4-hydroxy-androstenedione were in the range of $10^{-9} \mathrm{M}$ and $10^{-6} \mathrm{M}$, respectively (Table 1). Flavonoid

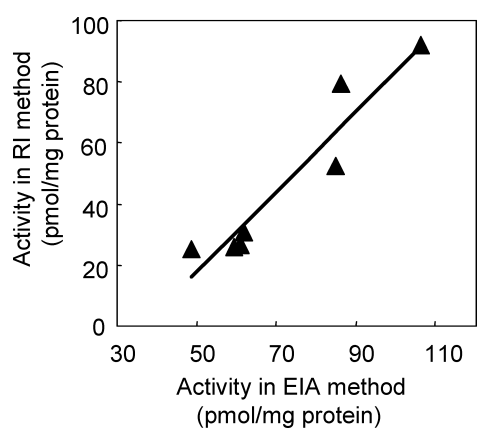

Fig. 3. Linear Regression Analysis between EIA Method and RI Method

The incubation time was carried out for $30 \mathrm{~min}$. The reaction was carried out in the presence of 0.45 (EIA method) or 5.0 (RI method) $\mu \mathrm{g}$ of different batches pregnant or no pregnant rat ovary microsomes/tube. The average values from 3 separate experiments are shown. The S.D. was less than $2.2 \%$. chemicals which are known to inhibit aromatase activity in vitro were examined by the EIA methods. The $\mathrm{IC}_{50}$ values of apigenin, flavone, and 7-hydroxyflavone were in the range of $10^{-6} \mathrm{M}, 10^{-5} \mathrm{M}$ and $10^{-7} \mathrm{M}$, respectively (Table 1 ).

Screening of Effects of Test Chemicals on Aromatase Activity Using the optimized EIA or RI assay conditions, we studied the effects of 45 chemicals that we had previously report to act as EDs (Table 1). The inhibition curves of aromatase activity by six of these chemicals are shown in Fig. 5 . No significant differences of the $\mathrm{IC}_{50}$ values of these chemicals determined using the EIA compared to RI methods were noted. Concentration-dependent inhibitory effects of rose bengal, erythrosine, phloxine, allura red, gallic acid, and tributyltin (TBT) on aromatase activity were observed. The inhibitory effect of rose bengal was the strongest with an $\mathrm{IC}_{50}$ value in the range of $10^{-8} \mathrm{M}$. The second-strongest aromatase inhibitors were erythrosine and phloxine, whose $\mathrm{IC}_{50}$ values were in the range of $10^{-7} \mathrm{M}$. Allura red, gallic acid, and TBT also inhibited aromatase activity, with $\mathrm{IC}_{50}$ values in the
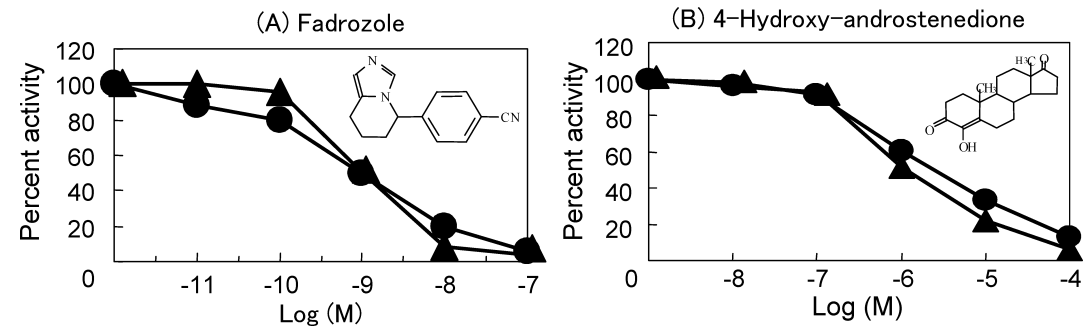

Fig. 4. Inhibition of Rat Ovary Aromatase Activity by Already-Known Aromatase Inhibitors

Aromatase activity without chemicals (0.1\% DMSO) was taken as $100 \%$. (A) Fadorozole, (B) 4-hydroxy-androstendione. $\bullet$; EIA method, $\mathbf{\Delta}$; RI method. The average values from 3 separate experiments are shown. The S.D. was less than $2.0 \%$.
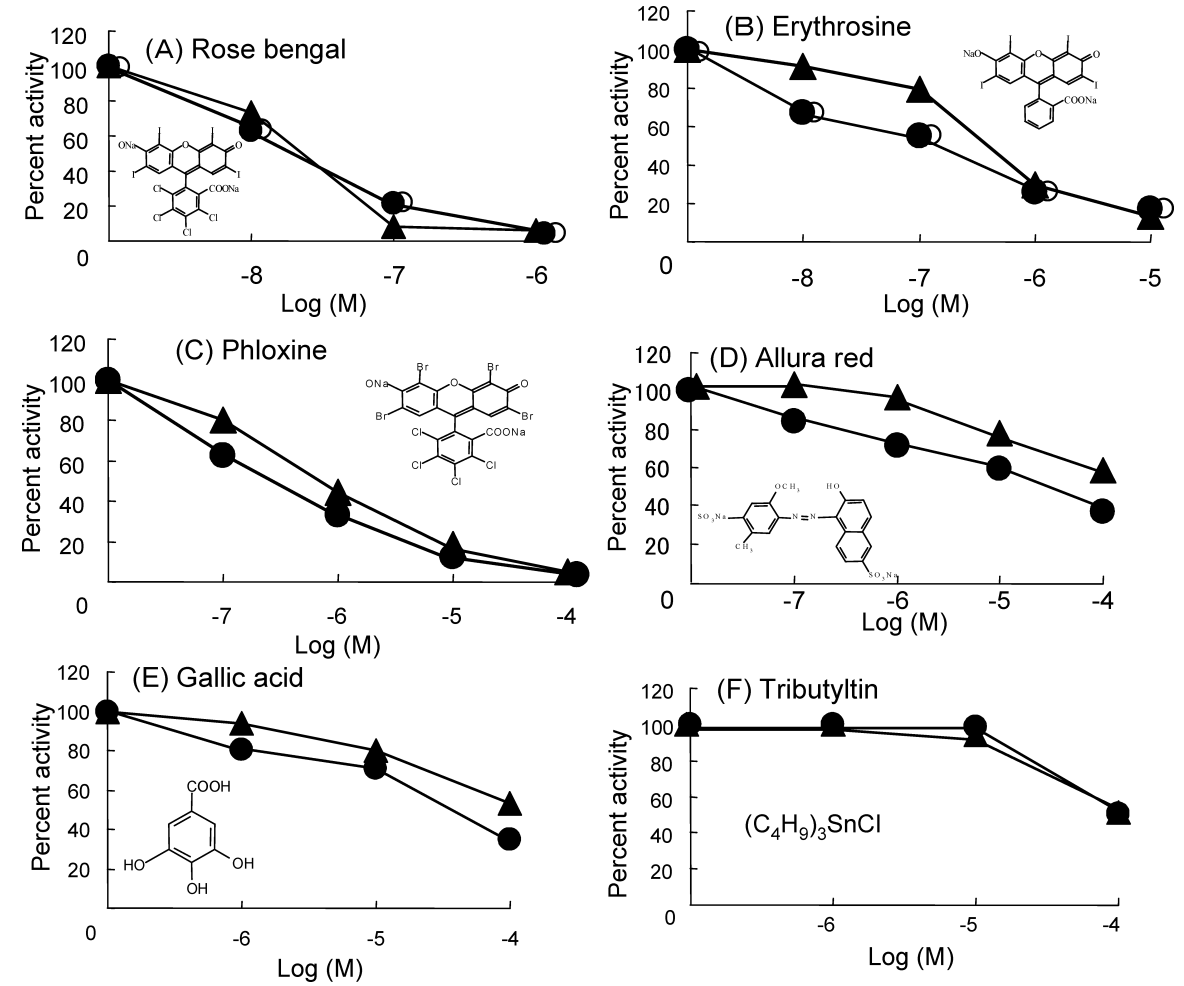

Fig. 5. Effect of Various Chemicals on Aromatase Activity

Aromatase activity without chemicals (0.1\% DMSO) was taken as $100 \%$. (A) Rose bengal, (B) erythrosine, (C) phloxine, (D) allura red, (E) gallic acid, (F) tributyltin. EIA method with $(\mathrm{O})$ or without $(\mathbf{O}) 50 \mathrm{pg} / \mathrm{ml}$ estrone; RI method $(\boldsymbol{\Delta})$. The average values from 3 separate experiments are shown. The S.D. was less than $2.3 \%$. 
range of $10^{-5} \mathrm{M}, 10^{-5} \mathrm{M}$, and $10^{-4} \mathrm{M}$, respectively. The other chemicals (acid red, others tins and plants, herbicides, parabens, styrene oligomers, and plastic antioxidants) listed in Table 1 did not affect the aromatase activity. Rose Bengal (Fig. 5A), erythrosine (Fig. 5B), and other all test chemicals in $50 \mathrm{pg} / \mathrm{ml}$ estrone solution did not affect the binding of estrone. These results indicated that the ELISA kit can be used to determine the estrone level without inference by chemicals.

\section{DISCUSSION}

In this present study, we established a novel non-radioactive assay that can measure the inhibition of aromatase by ED chemicals. When the experimenter uses RI, it is necessary to observe the Japanese law, and to construct facilities in conformity to the law. In addition, it is necessary to buy machinery and tools such as the liquid scintillation counters of high priced. Therefore, only the researcher of the institution where the RI equipment existed is able to measure aromatase activity. This assay was made possible by use of rat ovary microsomes in combination with an estrone ELISA kit. The measurable protein minimal dose was 0.42 and $3.3 \mu \mathrm{g}$ in EIA and RI method, respectively. The sensitivity of the EIA method was higher than that of the RI method. The correlation coefficient between the EIA method and the RI method was large, indicating a significant positive correlation between them.

In this study six aromatase inhibitors were used, namely fadrozole (a non-steroidal inhibitor), 4-hydroxy-androstenedione (a steroidal inhibitor), TBT, apigenin, flavone, and 7hydroxyflavone (flavonoid inhibitors). Rat ovary aromatase activity was inhibited by them. These $\mathrm{IC}_{50}$ values did not have the difference too much from published values. ${ }^{13,15-19)}$ These values were closer to the values that had been obtained by the human placenta method than the KGN method (Table $1)$. Our results clearly show that these chemicals act as aromatase inhibitors in rat ovarian microsomes as well. The in vitro microsomal aromatase assay is limited to measuring the inhibitory effects of test chemicals on aromatase enzymatic activity through direct interaction with enzyme complex but does not provide any information on the effect of the test agent on the gene/protein machinery. However, our EIA method using rat ovary microsomes would be useful for predicting possible ED in rats, and as an aid to mechanistic studies of ED effects observed in the rat.

By using this non-radioactive aromatase assay (EIA method), we tested the inhibitory effect of 45 chemicals (Table 1) that had previously been reported to act as EDs or to have the possibility of causing such an effect, ${ }^{1-6)}$ and 6 of these chemicals inhibited the aromatase activity. Four of the 6 chemicals are synthetic red dyes that are widely used as food additives. In this study, rose bengal was the strongest aromatase inhibitor, with an $\mathrm{IC}_{50}$ value of $2.4 \times 10^{-8} \mathrm{M}$, and the strength of the inhibition was about $1 / 25$ of $\mathrm{IC}_{50}$ values of a known aromatase inhibitor, fadrozole, but was about 100 times that of 4-hydroxy-androstendione. Erythrosine and phloxine inhibited the aromatase activity with an $\mathrm{IC}_{50}$ value of $1.5 \times 10^{-7}$ and $3.2 \times 10^{-7} \mathrm{M}$, and the strength of the inhibition was about $1 / 100$ and 50 times that of fadrozole and 4hydroxy-androstendione, respectively. Allura red inhibited the aromatase activity with an $\mathrm{IC}_{50}$ value of $2.4 \times 10^{-5} \mathrm{M}$. Red dyes are widely used as dyestuffs in agricultural products, in bakery items, in medicine and in cosmetics. ${ }^{20)}$ In Japan, the quantities of these 4 synthetic red dyes (rose bengal, erythrosine, phloxine, and allura red) consumed were $625.5,2,252$, 1,751 , and $738.5 \mathrm{~kg} /$ year, respectively. ${ }^{21)}$ The $\mathrm{LD}_{50}$ values of rose bengal in mice, erythrosine in mice, phloxine in mice and rats, and allura red in rats and dogs are 6480, 6800, 6800 and 7100 , and $>10000$ and $>5000 \mathrm{mg} / \mathrm{kg}$ body weight (BW), respectively. ${ }^{22)}$ The acceptable daily intake (ADI) of erythrosine and allura red is $0-0.1$ and $0-7.0 \mathrm{mg} / \mathrm{kg} \mathrm{BW}$, respectively. However, the ADI of rose bengal and phloxine have not been decided. ${ }^{23)}$

In the comet assay with mouse organs, these 4 red dyes induced DNA damage in the glandular stomach, colon, and/or urinary bladder. ${ }^{24)}$ Erythrosine $(0.1 \mathrm{mg} / \mathrm{mg}$ mitochondrial protein) completely inhibited mitochondrial respiration in the rat liver and kidney, ${ }^{25}$ and glucuronidation of $p$-nitrophenol and androsterone. ${ }^{26)}$ Erythrosine may interact with DNA repair enzymes and/or with DNA, ${ }^{27,28)}$ and has estrogen-like growth stimulatory properties in human breast cancer cells, ${ }^{28)}$ but does not show mutagenicity or genotoxicity ${ }^{29,30)}$ Administrating of rose bengal in mice induced colloid goiters and thyroid adenomas $^{31)}$ and decreased in serum levels of triiodothyronine and thyroxine. ${ }^{32)}$ Upon feeding of phloxine in male mice, body weight increased significantly, but phloxine is not carcinogenic. ${ }^{33}$ ) Furthermore, phloxine is not mutagenic $^{34)}$ and not teratogenic. ${ }^{35)}$ Upon feeding of allura red as well as phloxine in the F1 generation in mice, the male/female ratio was significantly reduced, and the body weight of offspring was significantly increased. ${ }^{36)}$ Allura red inhibited mitochondrial respiration, ${ }^{24)}$ but did not affect glucuronidation of $p$-nitrophenol or androsterone. ${ }^{25)}$ Allura red is negative to Salmonella, ${ }^{37)}$ and is not carcinogenic in rats ${ }^{38)}$ or mice. ${ }^{39)}$ One teratology study with allura red in rats showed negative results, ${ }^{40)}$ while another showed reduced ossification of the hyoid bone. ${ }^{41)}$ Allura red shows both physical and behavioral toxicity in developing rats. ${ }^{42}$ Though the effects thought to be EDs are reported to these 4 red dyes, it is impossible to explain from in vitro aromatase inhibitory effect simply. It is thought that the further investigation is necessary.

TBT and tri- $n$-phenyltin (TPT) are used in antifouling paints and wood preservatives. TBT and TPT are suspected to inhibit aromatase activity and cause imposex in gastropods. ${ }^{17,43)}$ In this study, TBT slightly inhibited the aromatase activity with an $\mathrm{IC}_{50}$ of $1.0 \times 10^{-4} \mathrm{M}$, but 2 other organotin compounds had no effect on the activity. These findings agree with those of Ohno et al. ${ }^{11)}$ The induction of imposex in gastropods by organotin compounds may be due to inhibition of aromatase, ${ }^{44}$ but our results suggested that the induction of imposex in gastropods by organotin compounds occurs via some mechanism other than inhibition of aromatase activity. $^{11,45)}$

We have been studying the endocrinological effects of the constituents of plants, and reported that green tea extract catechins inhibited aromatase activity in vitro. ${ }^{10)}$ In this study, we examined the effects of aromatase activity of some of typical plant constituents, and found that gallic acid, which is found in almost all plants, inhibited the aromatase activity with an $\mathrm{IC}_{50}$ of $3.4 \times 10^{-5} \mathrm{M}$, but 6 other constituents had no 
effect on the activity. Gallic acid is used for making dyes and inks, and seems to have anti-fungal and anti-viral properties. $^{46)}$ Furthermore, gallic acid acts as an antioxidant ${ }^{47)}$ and helps to protect organisms against cancer cells without harming healthy cells. ${ }^{48)} 7$-Hydroxyflavone was the most effective aromatase inhibitor in the plants (Table 1). This chemical induced a change in the absorption spectrum of the aromatase cytochrome P-450 which is indicative of substrate displacement. ${ }^{19)}$ Gallic acid may thus compete with steroids in their interaction with certain monooxygenases and thereby alter steroid hormone metabolism as well as flavones.

The novel non-radioactive aromatase assay that we established in this report has high sensitivity, and can be performed using a smaller amount of rat ovary microsomes than the RI method. It is thought that this EIA method would be useful for measuring the aromatase activity of microstructures. We are measuring the aromatase activity of brain slices of rats treated with ED chemicals using the EIA method. Some of the synthetic red dyes that are widely used as food additives were shown in this study to inhibit aromatase activity, and their ADI values have not yet been decided. We do not easily describe that chemicals which inhibit the aromatase activity in in vitro assay are EDs. Chemicals do various effects in vivo and it is known that the results of in vivo and in vitro are not simply comparable. However, the $\mathrm{IC}_{50}$ values found here for the synthetic red dyes were very low compared with the ADI and $\mathrm{LD}_{50}$ values. Artificial food colors are known to affect childhood behavior. ${ }^{49)}$ Recently, Bole and $\mathrm{Ueda}^{50)}$ shown that rose bengal was a potent inhibitor of glutamate uptake into synaptic vesicles. The report that rose bengal influenced the thyroid gland that is the target organ of EDs is remarkable. It is reported that the effect of the chemicals on the thyroid gland influences intelligence and the behavior. We therefore plan to examine the influence of these chemicals on the central nervous system in vitro and in vivo.

\section{REFERENCES AND NOTES}

1) Satoh K., Nagai F., Aoki N., Nishijima M., Yakugaku Zasshi, 120, 1429-1433 (2000).

2) Satoh K., Nagai F., Aoki N., J. Health Sci., 47, 495-501 (2001).

3) Satoh K., Nagai F., Ann. Rep. Tokyo Metr. Inst. P. H., 53, 265-267 (2002).

4) Satoh K., Ohyama K., Aoki N., Iida M., Nagai F., Food Chem. Toxicol., 42, 983-993 (2004).

5) Satoh K., Nonaka R., Ikeda M., Satoh T., Kamimura H, Nagai F., Ann. Rep. Tokyo Metr. Inst. P. H., 55, 307-314 (2004).

6) Satoh K, Nonaka R., Ohyama K., Nagai F., J. Health Sci., 51, 557568 (2005).

7) Simpson E. R., Mahendroo M. S., Means G. D., Kilgore M. W., Hinshelwood M. M., Graham-Lorence S., Amarneh B., Ito Y., Fisher C. R., Michael M. D., Endocr. Rev., 15, 342-355 (1994).

8) Siiteri P. K., Thompson E. A., J. Steroid Biochem., 6, 317-322 (1975).

9) Numazawa M., Mutsumi A., Asano N., Ito Y., Steroids, 58, 40-46 (1993).

10) Satoh K., Sakamoto Y., Ogata A., Nagai F., Mikuriya H., Numazawa M., Yamada K., Aoki N., Food Chem. Toxicol., 40, 925-933 (2002).

11) Ohno K., Araki N., Yanase T., Nawata H., Iida M., Toxicol. Sci., 82, $443-450$ (2004)

12) Nishi Y., Yanase T., Mu Y., Oba K., Ichino I., Saito M., Nomura M., Mukasa C., Okabe T., Goto K., Takayanagi R., Kashimura Y., Haji M., Nawata H., Endocrinology, 142, 437-445 (2001).
13) Odum J., Ashby J., Toxicol. Lett., 129, 119-122 (2002).

14) Bradford M. M., Anal. Biochem., 72, 248-254 (1976).

15) Dukes M., Edwards P. N., Large M., Smith I. K., Boyle T., J. Steroid Biochem. Mol. Biol., 58, 439- 445 (1996).

16) Njar V. C., Grun G., Hartmann R. W., J. Enzyme Inhib., 9, 195-202 (1995).

17) Heidrich D. D., Steckelbroeck S., Klingmuller D., Steroids, 66, 763 769 (2001).

18) Le Bail J. C., Pouget C., Fagnere C., Basly J. P., Chulia A. J., Habrioux G., Life Sci., 68, 751-761 (2001).

19) Ibrahim A. R., Abul-Hajj Y. J., J. Steroid Biochem. Mol. Biol., 37, $257-260$ (1990).

20) Nishioka H., Mutat. Res., 38, 345 (1976).

21) 2006 Marketing research of Food additives (Table 9), Newspaper of Food Chemistry in Japan, 2007/01/11.

22) Poulsen E., Food Addit. Contam., 8, 125-133 (1991).

23) "Methods of Analysis in Health Science 2005," ed. by Pharm. Soc. Japan, Kanehara, Tokyo, Japan, 2005, p. 351.

24) Sasaki Y. F., Kawaguchi S., Kamaya A., Ohshita M., Kabasawa K., Iwama K., Taniguchi K., Tsuda S., Mutat. Res., 519, 103-119 (2000).

25) Reyes F. G., Valim M. F., Vercesi A. E., Food Addit. Contam., 13, 5 $11(1996)$

26) Kuno N., Mizutani T., J. Toxicol. Environ. Health, Part A, 68, 14311444 (2005).

27) Lackdawalla A. A., Netrawali M. S., Mutat. Res., 204, 131-139 (1988).

28) Dees C., Askari M., Garrett S., Gehrs K., Henley D., Ardies C. M., Environ. Health Perspect., 105 (Suppl.), 625-632 (1997).

29) Haveland-Smith R. B., Combes R. D., Bridges B. A., Mutat. Res., 88, $1-15$ (1981)

30) Rogers C. G., Boyes B. G., Matila T. I., Heroux-Metcalf C., Clayson D. B., Mutat. Res., 205, 415-423 (1988)

31) Ito A., Watanabe H., Naito M., Aoyama H., Nakagawa Y., Fujimoto N., J. Natl. Cancer Inst., 77, 277-281 (1986).

32) Kurebayashi H., Fukuoka M., Nishimaki-Mogami T., Minegishi K., Tanaka A., J. Toxicol. Sci., 13, 61-70 (1988).

33) Ito A., Fujimoto N., Okamoto T., Ando Y., Watanabe H., Food Chem. Toxicol., 32, 517-220 (1994).

34) Maus K. L., Nestmann E. R., Kowbel D. J., Mutat. Res., 91, 315-320 (1981).

35) Seno M., Fukuda S., Umisa H., Food Chem. Toxicol., 22, 55-60 (1984).

36) Tanaka T., Toxicology, 92, 169-177 (1994).

37) NTP (2000). Allura red. Avaolable at National Toxicology Program website: http//ntpserver.niehs.nih.gov/cgi/iH_Indexes/ALL_SRCH/iH_ ALL_SRCH_Frames.html. Acccessed November 13, 2000.

38) Borzelleca J. F., Olson J. W., Reno F. E., Food Chem. Toxicol., 27, 701-705 (1989).

39) Borzelleca J. F., Olson J. W., Reno F. E., Food Chem. Toxicol., 29, 313-319 (1991).

40) Collins T. F., Black T. N., Welsh J. J., Brown L. H., Food Chem. Toxicol., 27, 707-713 (1989).

41) Collins T. F., Black T. N., Welsh J. J., Brown L. H., Toxicol. Industr. Health, 5, 937-948 (1989).

42) Vorhees C. V., Butcher R. E., Brunner R. L., Wootten V., Sobotka T. J., Toxicology, 28, 207-217 (1983).

43) Saitoh M., Yanase T., Morinaga H., Tanabe M., Mu Y. M., Nishi Y., Nomura M., Okabe T., Goto K., Takayanagi R., Nawata H., Biochem. Biophys. Res. Commun., 289, 198-204 (2001).

44) Bettin C., Oehlmann J., Stroben E., Helgol. Meeresun., 50, 299-317 (1996).

45) Sanderson J. T., Boerma J., Lansbergen G. W., van den Berg M., Toxicol. Appl. Pharmacol., 182, 44-54 (2002).

46) Namba T., Kurokawa M., Kadota S., Shiraki K., Yakugaku Zasshi, 118, 383-400 (1998)

47) Que F., Mao L., Zheng X., Asia Pac. J. Clin. Nutr., 16 (Suppl.), 196203 (2007).

48) Faried A., Kurnia D., Faried L. S., Usman N., Miyazaki T., Kato H., Kuwano H., Int. J. Oncol., 30, 605-613 (2007).

49) Pollock I., Warner J. O., Arch. Dis. Child., 65, 74-77 (1990).

50) Bole D. G., Ueda T., Neurochem. Res., 30, 363-369 (2005). 